\title{
UPAYA PEMBINAAN SIKAP BERWIRAUSAHA REMAJA MESJID NURUL IMAN KAMPUNG JAWA TOMOHON MELALUI PELATIHAN KETERAMPILAN
}

\author{
Zuldesmi \\ Program Studi Teknik Mesin, Fakultas Teknik, \\ Universitas Negeri Manado \\ zuldesmi@unima.ac.id
}

\begin{abstract}
Abstrak
Semakin membengkaknya pengangguran di kalangan usia muda produktif semakin menunjukkan bahwa ketersediaan lapangan kerja yang sangat terbatas. Hal ini tentu saja disebabkan oleh banyak faktor yang sangat kompleks. Namun demikian, salah satu solusi yang sangat realistis untuk diwujudkan adalah melalui usaha peningkatan jumlah wirausaha terutama di kalangan muda produktif, yang dalam hal ini dapat diwakili oleh kelompok karang taruna di dusun-dusun atau minimal di tingkat kelurahan. Salah satu alternatif solusinya adalah melalui pemberdayaan generasi muda agar mampu berwirausaha melalui pelatihan keterampilan produksi komoditas yang dapat diterima pasar secara mudah. Sasaran antara yang strategis adalah kelompok pemuda berusia produktif yang secara organisatoris telah terbentuk sampai ke tingkat dusun, dan minimal di tingkat Kelurahan. Salah satu keterampilan yang mampu menghasilkan produk yang masih terbuka luas pemasarannya adalah bidang kerajinan las. Karena itu, konsep pemberdayaan sumber daya manusia, khususnya pemuda, dalam kegiatan ini dilandasi dengan kondisi eksisting di masyarakat, yang memerlukan upaya pemberdayaan dalam wacana pembangunan masyarakat dihubungkan dengan konsep mandiri, partisipasi, jaringan kerja dan keadilan. Dalam kegiatan Program Kemitraan Masyarakat (PKM) ini, akan dilakukan pelatihan dasar las listrik secara intensif pada pemuda usia produktif melalui organisasi Pemuda Remaja Mesjud Kampung Jawa Tomohon, yaitu dimulai dengan penambahan ketearmpilan yang berguna dalam mendukung munculnya wirausaha baru yang kreatif, peningkatan kecakapan hidup (life skill), dan pola pemasaran yang bersifat kolaboratif dengan memanfaatkan keunggulan Tomohon sebagai kota industri. Hasilnya lebih dari $50 \%$ peserta generasi muda telah mengusai sistem pengelasan dengan baik. Selain itu, sebagian besar para remaja usia produktif telah memiliki keterampilan dan ilmu pengetahuan untuk mendapatkan atau menciptakan lapangan kerja.
\end{abstract}

Kata kunci; pengangguran, produkif, pengelasan, karang taruna 


\section{PENDAHULUAN}

\section{Analisis Situasi}

Menurut Badan Pusat Statistik (BPS), jumlah angkatan kerja pada Februari 2019 sebanyak 136,18 juta orang, naik 2,24 juta orang dibanding Februari 2018. Meskipun tercatat Tingkat Pengangguran Terbuka (TPT) per Februari 2019 ada di angka 5,01 persen dari tingkat partisipasi angkatan kerja (membaik dibanding posisi Februari 2018 yakni 5,13 persen), namun hal ini masih sangat menngkhawatirkan. Jenjang pendidikan yang memiliki TPT paling tinggi adalah Sekolah menengah Kejuruan yang mencapai 8, 63 persen. Semakin membengkaknya pengangguran di kalangan usia muda produktif semakin menunjukkan bahwa ketersediaan lapangan kerja yang sangat terbatas. Hal ini tentu saja disebabkan oleh banyak faktor yang sangat kompleks. Namun demikian, salah satu solusi yang sangat realistis untuk diwujudkan adalah melalui usaha peningkatan jumlah wirausaha terutama di kalangan muda produktif, yang dalam hal ini dapat diwakili oleh kelompok karang taruna di dusun-dusun atau minimal di tingkat kelurahan. Salah satu alternatif solusinya adalah melalui pemberdayaan generasi muda agar mampu berwirausaha melalui pelatihan keterampilan produksi komoditas yang dapat diterima pasar secara mudah. Sasaran antara yang strategis adalah kelompok pemuda usia produktif yang secara organisatoris telah terbentuk sampai ke tingkat dusun, dan minimal di tingkat Kelurahan. Salah satu keterampilan yang mampu menghasilkan produk yang masih terbuka luas pemasarannya adalah bidang kerajinan las. Karena itu, konsep pemberdayaan sumber daya manusia, khususnya pemuda, dalam kegiatan ini dilandasi dengan kondisi eksisting di masyarakat, yang memerlukan upaya pemberdayaan dalam wacana pembangunan masyarakat dihubungkan dengan konsep mandiri, partisipasi, jaringan kerja dan keadilan.

Dalam kegiatan Program Kemitraan Masyarakat (PKM) ini, akan dilakukan pelatihan dasar las listrik secara intensif kepada para pemuda usia produktif yang bernaung di organisasi Pemuda Remaja Mesjid Nurul Iman Kampung Jawa Tomohon, yaitu dimulai dengan penambahan keterampilan yang berguna dalam mendukung munculnya wirausaha baru yang kreatif, peningkatan kecakapan hidup (life skill), dan pola pemasaran yang bersifat kolaboratif dengan memanfaatkan keunggulan Tomohon sebagai kota industri. Tujuan kegiatan pengabdian masyarakat yang dilakukan ini adalah transfer ilmu pengetahuan dan teknologi agar masyarakat.

1. Memiliki pengetahuan yang cukup tentang pengetahuan dan ketrampilan dasar Teknologi Las Listrik. 
2. Memiliki pengetahuan, kesadaran dan motivasi untuk melaksanakan prosedur pengelolaan bengkel las skala kecil sesuai standar kerja las.

3. Memiliki kesadaran terhadap prosedur dan penerapan keselamatan kerja las.

\section{Permasalahan Mitra}

Dari hasil diskusi dan wawancara dengan ke mitra, maka pengusul mendapatkan kesimpulan tentang permasalahan yang dihadapi oleh mitra untuk dicarikan solusi yang tercantum di bawah ini:

1. Jumlah pengangguran usia muda produktif masih sangat banyak dan berpotensi menimbulkan permasalahan yang kompleks khususnya permasalahan ekonomi dan sosial.

2. Berdasarkan analisis awal, tingginya tingkat pengangguran disebabkan tidak dikuasainya keterampilan produktif yang dapat dijadikan sarana untuk mengembangkan kewirausahaan.

3. Umumnya tingkat pendidikan cukup berpengaruh pada kemampuan membuka kesempatan kerja, namun kurangnya keterampilan menyebabkan sangat sulit bagi mereka untuk memperoleh pekerjaan sesuai bidang yang mereka miliki sehingga memilih pekerjaan yang kurang produktif.
4. Masih sangat sedikit program pemberdayaan yang dilakukan untuk pemuda usia produktif, sehingga banyak yang belum tersentuh oleh upaya perbaikan taraf hidup.

5. Belum terjalinnya kemitraan yang kondusif antara dunia pendidikan dengan karang taruna sebagai representasi kelompok muda usia produktif sehingga belum dapat berlangsungnya penerapan hasil penelitian dan riset yang sesuai untuk pemberdayaan pemuda.

6. Diperlukannya upaya untuk memperoleh dan mentranformasikan pengetahuan, sikap dan keterampilan dari dan kepada warga masyarakat dalam memecahkan masalah pembangunan secara pragmatis melalui pendekatan interdisipliner, komprehensif, dan lintas sektoral.

\section{METODE PELAKSANAAN}

Dari permasalahan yang dihadapi oleh pengrajin tahu di atas maka metode penyelesaian yang digunakan adalah dengan beberapa pelatihan dan pendampingan dengan kegiatan seperti di bawah ini :

1. Membicarakan jenis pelatihan yang dibutuhkan para pemuda usia produktif

2. Menetapkan waktu pelaksanaan pelatihan 
3. Menetapkan lokasi pelaksanaan pelatihan

4. Menyusun modul pelatihan

5. Melengkapi alat dan bahan pelatihan

6. Tim turun kelapangan

7. Pelaksanaan Pelatihan

8. Evaluasi

Untuk menghasilkan hasil yang optimal dari kegiatan pelatihan ini, metode yang digunakan adalah :

1. Metode ceramah dan Tanya jawab

2. Metode demonstrasi

3. Metode praktikum

Partisipasi Mitra Dalam Pelaksanaan Program

Dalam program pelaksanaan PKM ini, kelompok pengrajin anyaman bambu berpartisipasi dalam bentuk:

- Menyediakan tempat pelatihan pengelasan

- Menyediakan sejumlah peserta pelatihan yang bertanggungjawab untuk mengikuti pelatihan.

- Memiliki tanggung jawab untuk memelihara dan merawat peralatan yang diberikan oleh pihak pertama.

- Menjaga keberlangsungan program.

\section{HASIL DAN PEMBAHASAN}

Untuk mengetahui pencapaian tujuan kegiatan dilakukan evaluasi. Bentuk evaluasi yang dilakukan adalah mengamati cara kerja peserta mengikuti pelatihan dan dinilai menurut kompetensi keterampilan pengelasan yang baik. Evaluasi tersebut dilakukan dengan 2 cara yaitu:

1. Pengamatan secara langsung dari instruktur terhadap sikap para peserta, kehadiran peserta dan tanya jawab setiap akan masuk pada topik yang baru.

2. Hasil tes keterampilan pengelasan dari masing-masing peserta .

\section{Metode Ceramah dan Tanya Jawab}

Dalam metode ceramah dan tanya jawab, tim pengabdian menyampaikan materi dalam bentuk power point dengan berbasis audio visual. Materi yang disampaikan tidak hanya dalam bentuk gambar, tapi juga ditampilkan dalam bentuk video pelatihan pengelasan, sehingga peserta pelatihan dapat melihat secara langsung bagaimana cara mengelas yang baik, sebelum praktek pengelasan yang sebenarnya dilakukan. Dalam sesi tanya jawab, banyak peserta pelatihan yang terlihat antusias dan aktif memberikan pertanyaan yang menyangkut tentang cara pengelasan yang benar. Keinginan peserta untuk memahami dan mengetahui materi sangat tinggi. 


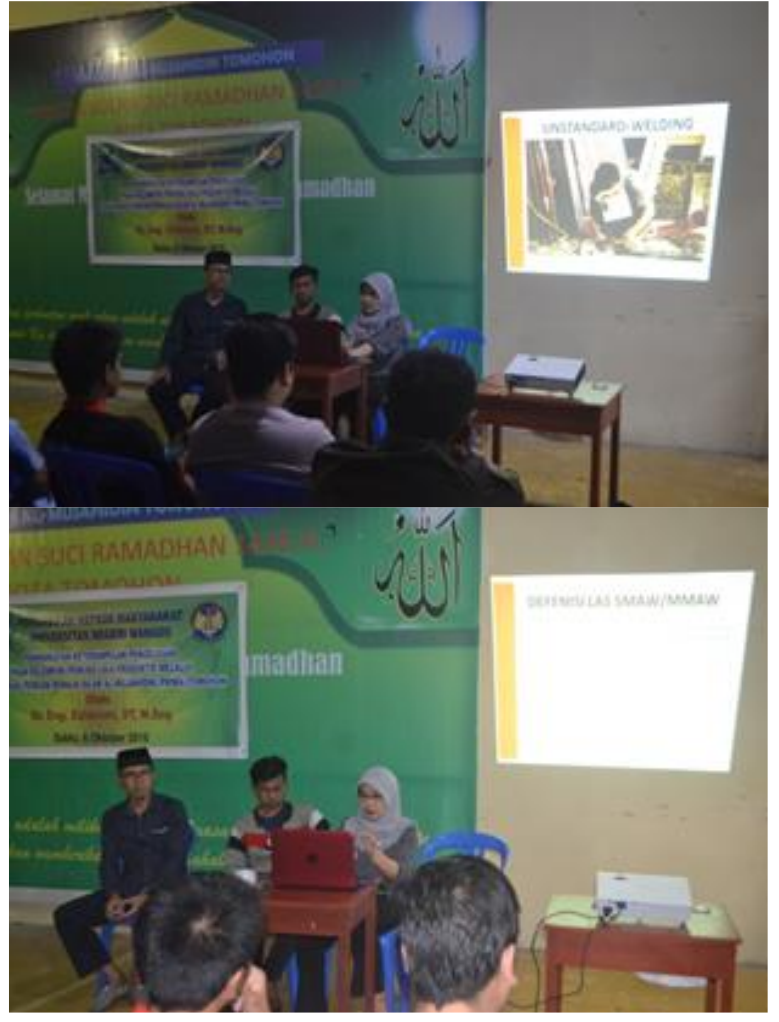

\section{Metode Pelatihan dan Praktikum}

Metode ini dilakukan melalui 2 tahap pelaksanaan. Pertama, tim melakukan proses pengelasan terlebih dahulu untuk menunjukkan kepada semua peserta cara pengelasan yang baik. Disamping itu juga ditunjukkan tentang safety tool (alat-alat keamanan) yang perlu digunakan pada saat proses pengelasan, seperti: helm las, sarung tangan las sepatu las dan lain-lainnya.

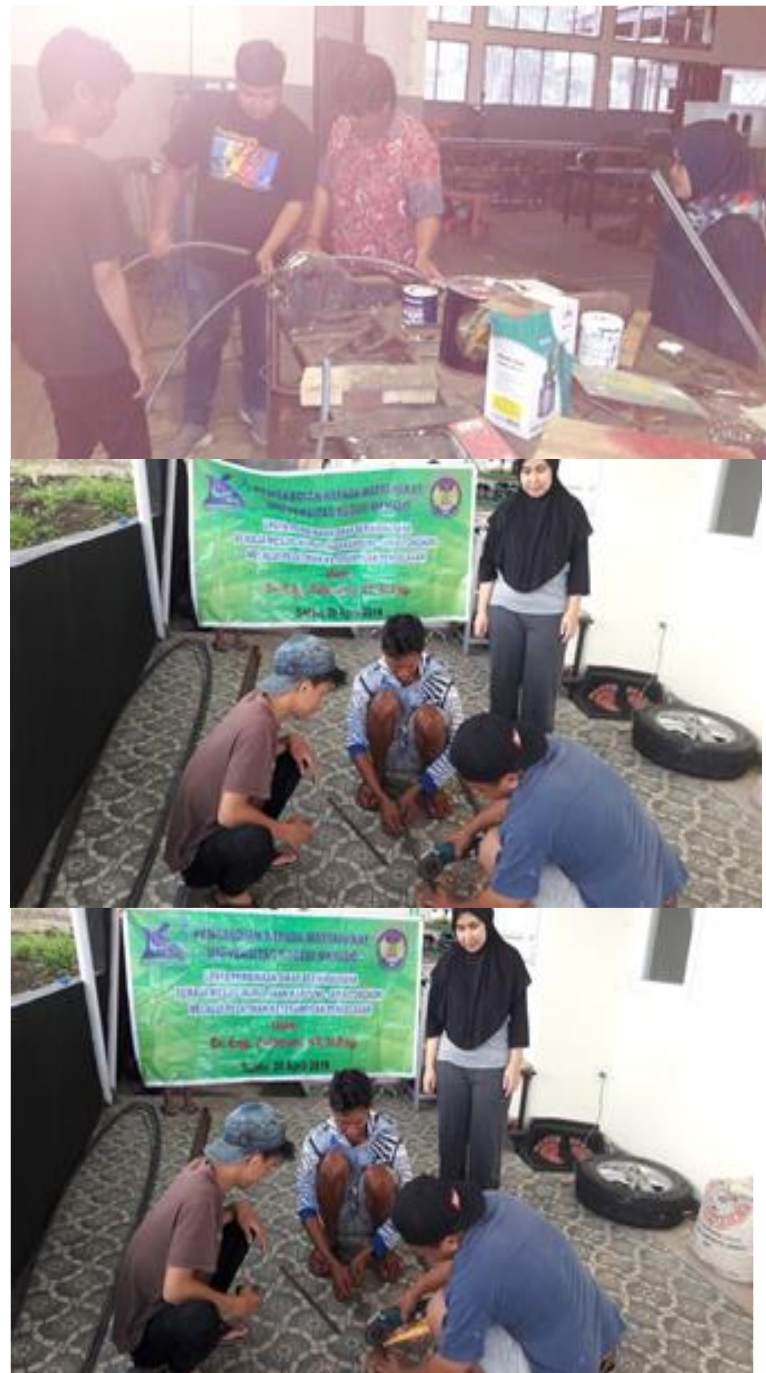

Tahap kedua dilakukan dengan cara memberikan kesempatan kepada setiap peserta untuk mempraktekkan secara langsung proses pengelasan. Proses pelatihan berlangsung penuh dinamika yang ditandai dengan tanya jawab anatara pelatih dan para pemuda remaja masjid dalam suasana santai. Meskipun pada awalnya a da ketakutan dan keraguan dari masing-masing peserta, karena proses pengelasan berhubungan dengan panas dan listrik. Namun, berkat pendekatan yang dilakukan oleh tim pengabdian dengan cara 
pemberian semangat dan motivasi, semua peserta mau dan mampu melaksanakan proses pengelasan dengan baik. Banyak diantara mereka yang akhirnya aktif membuat mencoba sendiri dan hanya sebagian kecil saja yang ragu-ragu dan hanya membantu teman lainnya yang bekerja. Hasil yang didapat kemudian diujicobakan dikalangan mereka sendiri dan ternyata hasilnya baik dan layak untuk digunakan dalam pembelajaran las logam. Dokumentasi kegiatan pengabdian kepada masyarakat dapat dilihat seperti pada gambar di bawah ini.

Para peserta pelatihan juga diberikan wawasan yang lebih luas tentang bagaimana kesempatan mereka untuk bisa memasuki dan membuka lapangan pekerjaan di bidang pengelasan seperti membuka bengkel las. Dalam hal ini, tim pengabdian juga memberikan bantuan dalam bentuk penyerahan satu set mesin las lengkap dengan safety tool yang diperlukan. Indikator keberhasilan dari kegiatan ini adalah:

1. Para peserta memiliki pengetahuan tentang teknik dan cara menggunakan mesin las.

2. Para peserta memiliki keterampilan tentang teknik dan cara mengelas yang baik

3. Para peserta memiliki sikap kewirausahaan dan mampu membina kerjasama antar kelompok untuk melakukan usaha perbengkelan las.

Kenyataan ini memberikan gambaran pada kita, bahwa sebagian besar para remaja putus sekolah usia produktif ini harus kita berikan bekal keterampilan, agar mereka dapat memasuki lapangan kerja atau membuka lapangan kerja sendiri di masa mendatang untuk itu kami berharap agar pihak terkait dapat membantu baik materil maupun spiritual, terutama Pemerintah kabupaten setempat sebagai pasilisator agar kami dapat melaksanakan kegiatan

\section{KESIMPULAN DAN SARAN}

\section{Kesimpulan}

1. Telah dilaksanakan pembinaan terhadap sebagian besar para remaja usia produktif untuk mendapatkan/menciptakan lapangan pekerjaan khususnya dibidang teknik pengelasan.

2. Lebih dari $50 \%$ peserta generasi muda telah mengusai sistem pengelasan dengan baik. Sisanya yang lain dari peserta pelatihan dalam kondisi cukup menguasai pengelasan tersebut.

3. Sebagian besar para remaja usia produktif telah memiliki keterampilan untuk mendapatkan atau menciptakan lapangan kerja.

\section{Saran}


Berdasarkan kesimpulan di atas masih ditemukan beberapa kelemahan dalam kegiatan pengabdian ini. Oleh karena itu perlu dilakukan refleksi sebagai umpan balik perencanaan tindakan pengabdian tahun berikutnya. Variasi penerapan teknologi las logam belum terlalu bisa dilaksanakan. Namun keterbatasan dana dan waktu menyebabkan kegiatan pengabdian ini lebih memfokuskan pada alat-alat yang lebih mudah dan murah membuatnya.

\section{KEPUSTAKAAN}

Dieter, G.E. Engineering design: A materials and processing approach. Tokyo: McGraw-Hill International Book Company. (1983).

Rizal Sani, Las Busur Manual 1, PPPG Teknologi Bandung, 1997

Ramli Soehatman, Sistem Manajemen Keselamatan \& Kesehatan Kerja, Dian Rakyat, Jakarta, 2010.

Strength of Materials. William Nash. Schaum"s Outlines, 1998.

The Lincoln Electric Company, The Procedure Handbook of Arc Welding, The Lincoln Electric Company, 1973

William D. Callister Jr., Material Science and Engineering: An Introduction. John Wiley\&Sons, 2004. 
Jurnal ABDIMAS, Vol. 12, No. 3, Desember 2019

ISSN: 1979-0953 | e-ISSN: 2598-6066 